\title{
SUITABILITY OF DRYIED POULTRY MANURE FOR USE AS ANIMAL FEED
}

\author{
Nesreen S. Mahmoud*
}

\begin{abstract}
The aim of this study was to determine the optimum quality of poultry manure dried at various layer thickness and temperatures. The effects of the depth of manure layer (1, 2 and $3 \mathrm{~cm}$ ) and dryer temperature (40, 50 and $60^{\circ} \mathrm{C}$ ) on the drying time and the quality of the dried manure as a safe animal feed were investigated. The results indicate that the optimum depth and temperature to dry manure in a heated air dryer is $3 \mathrm{~cm}$ and $60{ }^{\circ} \mathrm{C}$, respectively. Increasing the temperature and/or decreasing the depth of manure layer decrease the concentration of protein and amino acids in the dried manure. The temperature and depth of the manure layer did not affect the elemental composition of the dried manure. The presence and offensiveness of odour were reduced by $63.3 \%$ and $69.3 \%$, respectively. The majority of the panel members described the odour of the dried manure as that of grain. The drying process reduced the number of bacteria, yeast and mould, and E. Coli by 65.62\%-99.83\%, 74.07\%$99.63 \%$, and $99.97 \%$ respectively. The Salmonallae were destroyed completely at temperatures above $50{ }^{\circ} \mathrm{C}$.
\end{abstract}

Keywords: poultry manure, solar, drying, temperature, depth, moisture, protein, odour, minerals, bacteria, yeast and mould, E. coli, Salmonallae.

\section{INTRODUCTION}

The poultry industry is one of the largest and fastest growing food
production sectors in the world with meat and egg production
growing at an annual rate of $5 \%$ (Sims and Wolf, 1994). The 2016 Egyptian annual census data estimated the flock to be over 750 million birds with an estimated yearly output of 93,750 tonnes of manure (FAO, 2007). Storage and disposal of raw poultry manure has become an environmental problem because of the associated air, water and soil pollution (Benali and Kudra, 2006).

* Assistant Prof. of Ag. Eng. Dept., Faculty of Ag., Cairo University. 
Poultry manure begins to decompose immediately after excretion, giving off ammonia which can have adverse effects on the health and productivity of birds as well as the health of the farm workers (Pierson et al, 2005; and Amon et al., 2006). It can also serve as a breeding ground for pathogenic microorganisms, flies and other undesirable insects, a transmitting medium for diseases among birds and a source of odour caused by the activity of microorganisms in the manure (Berry and Miller, 2005; and Fares et al., 2005). Proper poultry manure management systems that will preserve the environment contribute to both animal and human health and return a profit on investment to the farmer need to be developed.

Drying can prevent environmental problems associated with storage and utilization of raw manure. Drying eliminates the stickiness of manure and minimizes the rate of deterioration from chemical and biological activities. Dried poultry manure can be used as a component of feed for ruminants (Lanyasunya et al. 2006; Hadjipanayiotou et al., 1993; El-Sayed, 1992; Islam and Hossain, 1990; Jakhmola et al., 1988; Daniet et al. 1983). Hadjipanayiotou et al. (1993) reported significant increase in goat milk production and reduced feeding costs when using diet supplemented with poultry manure.

The main aim of this study was to evaluate the suitability of dried manure as an animal feed. The specific objectives were to: (a) evaluate the drying behaviour of laying hen manure at temperatures in the range of $40-60^{\circ} \mathrm{C}$ and different depths of manure in the range of $1-3 \mathrm{~cm}$. and (b) determine the changes in the properties of the manure due to the drying process as measured by its nutritional value, pathogens content and presence and offensiveness of odour.

\section{MATERIALS AND METHODS}

\section{Drying Trays}

Three sets of trays, each set consisting of three replicate trays of the same dimensions, were constructed using galvanized metal sheets and used for the drying of poultry manure in the laboratory. Each tray has a drying surface area of $100 \mathrm{~cm}^{2}$. The depths of the trays were 1,2 , and $3 \mathrm{~cm}$ for the sets 1, 2 and 3, respectively. Figure 1 shows the dimensions of a drying tray. 


\section{Manure Collection and Preparation}

Poultry manure was obtained from a commercial layer's house. The manure was collected under battery cages of a laying house accommodating approximately 50,000 hens. The manure was collected and placed in clean plastic bags and transported to the Bioengineering Laboratory. Some characteristics of the poultry manure used in this study are presented in Table 1.

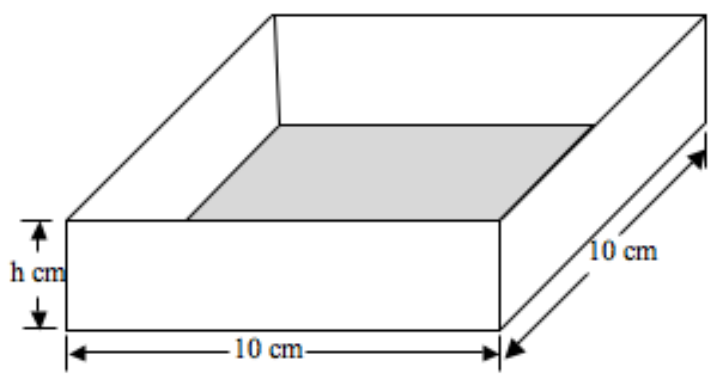

Figure 1: The dimensions of the drying tray $(\mathrm{h}=1,2$, or $3 \mathrm{~cm})$

Table 1: Characteristics of poultry manure used in study

\begin{tabular}{ll}
\hline Item & Measured value* \\
\hline Moisture content & $78.4 \%$ \\
Density & $960 \mathrm{~kg} / \mathrm{m}^{3}$ \\
Total solids & $215520 \mathrm{mg} / \mathrm{L}$ \\
Volatile solids & $139770 \mathrm{mg} / \mathrm{L}$ \\
Ash & $75750 \mathrm{mg} / \mathrm{L}$ \\
Total Chemical Oxygen Demand & $328500 \mathrm{mg} / \mathrm{L}$ \\
Soluble Chemical Oxygen Demand & $130000 \mathrm{mg} / \mathrm{L}$ \\
Total Kjedahl Nitrogen & $18960 \mathrm{mg} / \mathrm{L}$ \\
Ammonium Nitrogen & $9470 \mathrm{mg} / \mathrm{L}$ \\
Calcium & $19760 \mathrm{mg} / \mathrm{L}$ \\
Phosphorous & $5590 \mathrm{mg} / \mathrm{L}$ \\
Potassium & $4140 \mathrm{mg} / \mathrm{L}$ \\
pH & 8.40 \\
\hline
\end{tabular}

* dry basis

\section{Experimental Procedure}

The effects of three drying temperatures $\left(40,50\right.$ and $\left.60^{\circ} \mathrm{C}\right)$ and three manure depths $(1,2$ and $3 \mathrm{~cm})$ on the manure drying time and manure characteristics were investigated. The three sets of trays were weighted with a weighing scale (METTLER Balance model PM4600, Fisher 
Scientific, Montreal, Quebec, Canada). The trays were then filled to their respective depths with the manure and weighed. They were then placed in a forced draft oven (Isotemp Oven Model 655F, Fisher Scientific, Montreal, Quebec, Canada) adjusted to the required temperature. The drying rate was monitored by determining the change in weight at $2 \mathrm{~h}$ time intervals until there was no change in weight. The oven temperature was then readjusted to the next level and the same experimental procedure was followed. Three replications for each temperature-manure depth combination were carried out.

\section{Experimental Analysis}

The properties of the manure were determined before and after drying. The $\mathrm{pH}$, density, total solids, chemical oxygen demand, total Kjeldahl nitrogen, ammonia nitrogen and microbiological analyses were performed according to the procedures described in APHA (1998). The moisture content was determined using the oven method according to the procedure described in ASAE (1991). The elemental analyses (P, K, Ca) were performed according to the procedures described in the AOAC (1975). The total protein was determined using the Tecator Kjeltec Auto Analyzer (Model1026, Fisher Scientific, Montreal, Quebec, Canada). The amino acids were determined using the HFB-IBA (Heptafluorobutyric isobutyl esters of amino acids) Amino Acid derivatization Kit (Alltech Associates, Inc. Cat. No.18094) and the amino acids profile was determined using the gas chromatograph (Model-HP5890 Series II, Hewlett, Palo Alto, CA). The organoleptic test developed by Ghaly (1982) for measurement of odour from animal waste was used to measure the presence and offensiveness of odour in the dried poultry manure using the evaluation sheet in Figure 2.

\section{Experimental Analysis}

The properties of the manure were determined before and after drying. The $\mathrm{pH}$, density, total solids, chemical oxygen demand, total Kjeldahl nitrogen, ammonia nitrogen and microbiological analyses were performed according to the procedures described in APHA (1998). The moisture content was determined using the oven method according to the procedure described in ASAE (1991). The elemental analyses (P, K, Ca) were performed according to the procedures described in the AOAC (1975). The total 
protein was determined using the Tecator Kjeltec Auto Analyzer (Model1026, Fisher Scientific, Montreal, Quebec, Canada). The amino acids were determined using the HFB-IBA (Heptafluorobutyric isobutyl esters of amino acids) Amino Acid Derivatization Kit (Alltech Associates, Inc. Cat. No.18094) and the amino acids profile was determined using the gas chromatograph (Model-HP5890 Series II, Hewlett, Palo Alto, CA). The organoleptic test developed by Ghaly (1982) for measurement of odour from animal waste was used to measure the presence and offensiveness of odour in the dried poultry manure using the evaluation sheet in Figure 2.

\section{Odour evaluation data sheet}

Name:

Date:

A. Rate the samples to the presence of odor and the odor as to offensiveness according to the following scale using samples " 0 " as having 0 rating and samples " 10 " as having 10 rating.

\begin{tabular}{|l|c|l|c|}
\hline \multicolumn{2}{|c|}{ Presence } & \multicolumn{2}{c|}{ Offensiveness } \\
\hline No odour & 0 & No offensive odour & 0 \\
\hline Very faint & $1-2$ & Very faint offensive odour & $1-2$ \\
\hline Faint & $3-4$ & Faint offensive odour & $3-4$ \\
\hline Definite & $5-7$ & Definite offensive odour & $5-7$ \\
\hline Strong & $8-9$ & Strong offensive odour & $8-9$ \\
\hline Very strong & 10 & Very strong offensive odour & 10 \\
\hline
\end{tabular}

B. Describe the odor of each sample by giving an appropriate descriptive term. Possible terms that might be used are given in the list below or you may use a term of your choice which you feel properly describes the odor.
Mould, musty
Yeast
Fish
Ammonia
Stagnant water
Grain, animal feed
Sulphide, rotten eggs
Sour, fermented
Petroleum
Rotten cabbage, mercaptans
Earth
Other (Please specify) 
RATING

\begin{tabular}{cccc}
\hline Sample & $\begin{array}{c}\text { Presence } \\
\text { Rating }\end{array}$ & $\begin{array}{c}\text { Offensiveness } \\
\text { Rating }\end{array}$ & $\begin{array}{c}\text { Odour } \\
\text { Description }\end{array}$ \\
\hline 1 & & \\
\hline 2 & & \\
\hline 3 & & \\
\hline
\end{tabular}

Thank you for your time

Figure 2: Odour evaluation sheet (Ghaly, 1984)

\section{RESULTS AND DISCUSSION}

\section{Drying Effectiveness}

The data on the drying time, moisture and drying effectiveness at various manure depths and drying temperatures are presented in Table 2. The parameter "drying effectiveness" is defined in this study as the time needed to drive off $1 \mathrm{~g}$ of moisture from the manure. The results indicated that the $1 \mathrm{~cm}$ deep manure layer dried fastest at the three drying temperatures, followed by $2 \mathrm{~cm}$ deep manure layer and $3 \mathrm{~cm}$ deep manure layer. The thinner the manure layer, the lower the amount of moisture it contained and consequently a shorter time duration was required to drive off the moisture. The time required to dry the $2 \mathrm{~cm}$ deep manure layer was more than the time required to dry the $1 \mathrm{~cm}$ deep layer by about $106 \%$ at $40^{\circ} \mathrm{C}$, $100 \%$ at $50^{\circ} \mathrm{C}$ and $87 \%$ at $60^{\circ} \mathrm{C}$. The time required to dry the $3 \mathrm{~cm}$ deep manure layer was more than the time required to dry the $2 \mathrm{~cm}$ deep manure layer by $22 \%$ at $40^{\circ} \mathrm{C}, 12 \%$ at $50^{\circ} \mathrm{C}$ and $7 \%$ at $60^{\circ} \mathrm{C}$. This showed that the difference in drying time between the shallower and deeper manure layers decreased as the temperature increased.

\section{Total Protein and Amino Acids}

Ruffin and McCaskey (1990) reported that most poultry manure contains about $25 \%$ crude protein on a DM basis, about half of which derives from uric acid, which can be efficiently used by rumen microbes for 
protein production. Generally, nutrients in manure will vary from farm to farm depending on the quality of the ration offered to the birds, their age, amount of feed wasted, the amount of water spillage and more importantly, the type and amount of bedding used (Lanyasunya et al., 2006).

The total protein content and amino acids profile determined in this study for raw and dried manure are shown in Table 3. The raw manure used in this study contained $43.3 \%$ DM basis crude protein. Lanyasunya et al. (2006) reported crude protein content of $15.4 \%$ DM basis for raw poultry manure/litter. Trevino et al. (2002) reported crude protein content of $31.6 \% \mathrm{DM}$ basis for raw poultry manure/litter. The protein value reported in this study is higher than those reported by others due to the freshness and proper storage of the manure used in the study. Lanyasunya et al. (2006) stated that poultry manure may lose more than $75 \%$ of its nutritional value through volatilization, leaching and rotting as a result of poor manure handling.

Manure air-drying is used to increase the manure shelf life. However, Jakhmola et al., (1988) reported that drying of manure results in loss of nitrogen. This problem was not encountered in this study as the total protein concentration in dried manure was slightly and insignificantly lower than that in raw manure. Neither the temperature nor the depth of the manure layer appeared to have any significant effect on the final protein concentration.

The amino acids profile consisted of 12 amino acids: alanine, glutamic, threonine, arginine, phenylalamine, valine, methionine, histidine, serine, leucine, lysine and cystine. Generally, the drying process reduced the concentration of all amino acids in poultry manure. Increasing the ambient temperature and/or decreasing the manure depth decreased the concentration of amino acids in the dried manure. The highest values of amino acids were observed at the lowest drying temperature and the highest manure depth while the lowest values of amino acids were observed at the highest drying temperature and the lowest manure depth. 
Table 2: Drying time and drying effectiveness of poultry manure at various temperatures and depths

\begin{tabular}{|c|c|c|c|c|c|c|}
\hline \multirow{2}{*}{$\begin{array}{c}\text { Drying } \\
\text { Temperature } \\
\left({ }^{\circ} \mathrm{C}\right)\end{array}$} & \multirow{2}{*}{$\begin{array}{l}\text { Manure } \\
\text { Depth } \\
(\mathrm{cm})\end{array}$} & \multirow{2}{*}{$\begin{array}{l}\text { Drying } \\
\text { Time } \\
\text { (h) }\end{array}$} & \multicolumn{2}{|c|}{ Weight(g) } & \multirow{2}{*}{$\begin{array}{c}\text { Moisture } \\
\text { (g) }\end{array}$} & \multirow{2}{*}{$\begin{array}{c}\text { Drying } \\
\text { Effectiveness } \\
(\mathrm{h} / \mathrm{g})\end{array}$} \\
\hline & & & Initial & Final & & \\
\hline \multirow[t]{3}{*}{40} & 1 & 55 & 125.95 & 27.15 & 98.80 & 0.56 \\
\hline & 2 & 106 & 224.70 & 48.43 & 176.27 & 0.60 \\
\hline & 3 & 120 & 312.72 & 67.41 & 245.31 & 0.50 \\
\hline \multirow[t]{3}{*}{50} & 1 & 44 & 129.16 & 27.84 & 101.32 & 0.43 \\
\hline & 2 & 84 & 226.21 & 48.71 & 177.50 & 0.47 \\
\hline & 3 & 90 & 314.28 & 67.74 & 246.54 & 0.37 \\
\hline \multirow[t]{3}{*}{60} & 1 & 28 & 127.18 & 27.41 & 99.77 & 0.28 \\
\hline & 2 & 52 & 227.86 & 49.11 & 178.75 & 0.29 \\
\hline & 3 & 60 & 322.57 & 69.52 & 253.05 & 0.24 \\
\hline
\end{tabular}

Table 3: Effect of drying on protein and amino acids concentration in manure Amino Acids (\%DB)

Drying

Temp. Manure Total Ala Glu Thu Arg Phe Val Met His Ser Leu Lys Cys $\left({ }^{\circ} \mathrm{C}\right) \quad(\mathrm{cm}) \quad(\% \mathrm{DB})$

\begin{tabular}{|c|c|c|c|}
\hline \multirow[t]{3}{*}{40} & 1 & 40.6 & $\begin{array}{llllllllllll}1.27 & 1.32 & 0.30 & 0.25 & 0.43 & 0.47 & 0.22 & 0.22 & 0.40 & 0.90 & 0.34 & 0.05\end{array}$ \\
\hline & 2 & 42.2 & $\begin{array}{llllllllllll}1.39 & 1.39 & 0.34 & 0.34 & 0.47 & 0.50 & 0.25 & 0.25 & 0.45 & 0.98 & 0.40 & 0.06\end{array}$ \\
\hline & 3 & 42.4 & $\begin{array}{llllllllllll}1.46 & 1.42 & 0.36 & 0.36 & 0.49 & 0.52 & 0.26 & 0.27 & 0.47 & 1.03 & 0.43 & 0.06\end{array}$ \\
\hline \multirow[t]{3}{*}{50} & 1 & 39.4 & $\begin{array}{llllllllllll}1.25 & 1.31 & 0.27 & 0.23 & 0.41 & 0.46 & 0.20 & 0.20 & 0.39 & 0.87 & 0.32 & 0.03\end{array}$ \\
\hline & 2 & 41.5 & $\begin{array}{llllllllllll}1.36 & 1.37 & 0.31 & 0.32 & 0.46 & 0.49 & 0.23 & 0.23 & 0.42 & 0.96 & 0.38 & 0.04\end{array}$ \\
\hline & 3 & 41.6 & $\begin{array}{llllllllllll}1.44 & 1.39 & 0.33 & 0.33 & 0.48 & 0.50 & 0.25 & 0.26 & 0.43 & 0.99 & 0.41 & 0.05\end{array}$ \\
\hline \multirow[t]{3}{*}{60} & 1 & 39.4 & $\begin{array}{llllllllllll}1.18 & 1.09 & 0.21 & 0.18 & 0.37 & 0.44 & 0.15 & 0.13 & 0.35 & 0.80 & 0.27 & 0.02\end{array}$ \\
\hline & 2 & 40.0 & $\begin{array}{llllllllllll}1.30 & 1.23 & 0.27 & 0.22 & 0.42 & 0.46 & 0.19 & 0.19 & 0.39 & 0.87 & 0.32 & 0.04\end{array}$ \\
\hline & 3 & 40.2 & $\begin{array}{llllllllllll}1.36 & 1.26 & 0.31 & 0.27 & 0.44 & 0.47 & 0.21 & 0.22 & 0.41 & 0.91 & 0.35 & 0.04\end{array}$ \\
\hline $\begin{array}{l}\text { Raw } \\
\text { Manure }\end{array}$ & & 43.3 & $\begin{array}{llllllllllll}1.52 & 1.47 & 0.39 & 0.39 & 0.52 & 0.54 & 0.29 & 0.31 & 0.50 & 1.11 & 0.47 & 0.07\end{array}$ \\
\hline
\end{tabular}


Ala-Alanine, Glu-Glutamic, Th-Threonine, Arg- Arginine, PhePhenylalamine, Vla- Valine, Met- Methionine, His- Histidine, SerSerine, Leu- Leucine, Lys- Lysine, Csy- Cysteine

\section{Elemental Analyses}

Paul et al., (1993) reported that poultry manure contains a wide array of minerals such as phosphorous $(0.56-3.92 \%)$, potassium $(0.73-5.17)$ and calcium $(0.81$ - 6.13). Others elements such as magnesium $(\mathrm{Mg})$, sulphur $(\mathrm{S})$, manganese $(\mathrm{Mn})$, copper $(\mathrm{Cu})$, zinc $(\mathrm{Zn})$, chlorine $(\mathrm{Cl})$, boron (B), iron (Fe), and molybdenum (Mo) may also be present in the poultry manure. Most of these elemental nutrients originate from the feed, supplements, medications, and water consumed by the birds. The concentration of nitrogen, calcium, phosphorous and potassium in the dried poultry manure are shown in Table 4 . Very small changes in the concentration of $\mathrm{Ca}, \mathrm{P}$ and $\mathrm{K}$ occurred during the drying process. However, about $50 \%$ of the nitrogen was lost during the drying process. Both temperature and manure depth did not have any significant effect on the elemental composition in the dried manure.

\section{Odor}

At the start of a new experiment, the odor given off near the oven during the drying process was noticeable. However, when the drying process progressed, the presence and offensiveness of the odor decreased with the time and the final product (dried manure) did not have any offensive odor. The results of the organoleptic test showed that both the presence and offensiveness of the dried poultry manure odor were reduced by $65.3 \%$ and $69.3 \%$, respectively (as compared to that of the fresh poultry manure). The odor present in the dried manure was not offensive. 33.3\% of the panel members described the odor as that of grain, $20 \%$ described it as a mold musty odor, $13.3 \%$ described it as that of ammonia, 13.3 described it as sour or fermented odor, $6.7 \%$ described it as fish odor, $6.7 \%$ described it as yeast odor ad $6.7 \%$ described it as sulfide or rotten eggs odor). Mondinia et al. (1996) reported that active drying is one of the main techniques employed to prevent losses of $\mathrm{NH}_{3}$ and development of undesirable odor from poultry manure. 


\section{Microbial Analysis}

A major obstacle to the feeding of poultry manure as a protein supplement for ruminants is pathogenic organisms (Lanyasunya et al., 2006). However, this problem may be minimized by proper manure handling. Raw poultry manure contains many potentially harmful pathogens, such as Salmonella and E. coli. Fortunately, these potentially harmful bacteria can be killed with mild heat $\left(60^{\circ} \mathrm{C}\right)$.

The microbial count in manure attained in this study is presented in Table 5. Generally, a high number of bacteria $\left(477 \times 10^{7}\right.$ cells/g manure) were found in the raw manure. The drying process reduced the number of bacteria by $65.62 \%-99.83 \%$ (from $477 \times 10^{7}$ to $2.1 \times 10^{7}-75 \times 10^{7}$ cells/g manure). The initial number of yeast and mold cells in raw manure was 2700 cells/g manure. The drying process reduced the number of yeast and mold cells by $74.07 \%-99.63 \%$ (to $<10$ cells/g manure). The initial number of $E$. coli cells in the raw manure was 21,986,666 cells/g manure. The drying process reduced the number of E. coli by $99.97 \%$ (to $<10$ cells/g manure). Salmonellae were detected in the dried manure samples collected after the drying process of the $3 \mathrm{~cm}$ manure layer at $40^{\circ} \mathrm{C}$. The results indicated that the higher the drying temperature cycle and the thinner the manure layer, the smaller the number of microbes present in the dried manure which make it more suitable for animal feeding. Hadjipanayiotou et al. (1993) didn't encounter any health problems with ruminants fed on diet mixed with $33 \%$ poultry manure.

Table 4: Essential elements in raw and dried poultry manure

\begin{tabular}{cccccc}
\hline \multirow{2}{*}{$\begin{array}{c}\text { Drying } \\
\text { Temperature }\end{array}\left(\begin{array}{c}\text { Manure } \\
\text { Depth }\end{array}\right.$} & \multicolumn{4}{c}{ Elements (\% DB) } \\
\cline { 3 - 6 }$\left({ }^{\circ} \mathrm{C}\right)$ & $(\mathrm{cm})$ & Nitrogen & Calcium & Phosphorous & Potassium \\
\hline 40 & 1 & 4.92 & 9.15 & 2.46 & 1.91 \\
& 2 & 4.63 & 9.16 & 2.45 & 1.90 \\
& 3 & 4.48 & 9.16 & 2.46 & 1.91 \\
50 & 1 & 4.45 & 9.15 & 2.45 & 1.90 \\
& 2 & 4.35 & 9.14 & 2.45 & 1.89 \\
& 3 & 4.23 & 9.14 & 2.46 & 1.90 \\
60 & 1 & 4.16 & 9.14 & 2.45 & 1.89 \\
& 2 & 3.99 & 9.13 & 2.44 & 1.90 \\
& 3 & 3.92 & 9.13 & 2.45 & 1.89 \\
\hline Raw Manure & & 8.8 & 9.17 & 2.48 & 1.92 \\
\hline
\end{tabular}


Table 5: Average microbial count in raw and dried poultry manure

\begin{tabular}{cccccc}
\hline $\begin{array}{c}\text { Drying } \\
\text { Temperature } \\
\left({ }^{\circ} \mathrm{C}\right)\end{array}$ & $\begin{array}{c}\text { Drying } \\
\text { Depth } \\
(\mathrm{cm})\end{array}$ & $\begin{array}{c}\text { Bacteria } \\
\left(10^{4}\right. \\
\text { cells/g) }\end{array}$ & $\begin{array}{c}\text { Yeast/Mould } \\
(\text { cells/g) }\end{array}$ & $\begin{array}{c}\text { E. Coli } \\
\left(10^{4}\right. \\
\text { cells/g) }\end{array}$ & $\begin{array}{c}\text { Salmonellae } \\
\text { (preserve })\end{array}$ \\
\hline 40 & 1 & 55000 & 250 & 10 & PP \\
& 2 & 69000 & 370 & 20 & PP \\
& 3 & 75000 & 430 & 30 & PP \\
50 & 1 & 2100 & 170 & $<10$ & ND \\
& 2 & 2900 & 210 & 10 & ND \\
& 3 & 4100 & 310 & 20 & ND \\
60 & 1 & 440 & $<10$ & $<10$ & ND \\
& 2 & 530 & $<10$ & $<10$ & ND \\
& 3 & 620 & $<10$ & $<10$ & ND \\
\hline Raw Manure & & 477000 & 2700 & 2290 & PP \\
\hline
\end{tabular}

$\mathrm{PP}=$ partially present $\mathrm{ND}=$ not detected

\section{CONCLUSIONS}

The results indicate that the optimum depth and temperature to dry manure in the air dryer is $3 \mathrm{~cm}$ and $60^{\circ} \mathrm{C}$, respectively. Increasing the temperature and/or decreasing the manure depth decreases the concentration of protein and amino acids in the dried manure. The temperature and manure depth did not affect the elemental composition of the dried manure. The presence and offensiveness of odour were reduced by $63.3 \%$ and $69.3 \%$ respectively. The drying process reduced the number of bacteria, yeast and mould, and E. Coli by $65.62 \%-99.83 \%, 74.07 \%$ $99.63 \%$, and $99.97 \%$ respectively. The Salmonallae were destroyed completely at temperatures above $50^{\circ} \mathrm{C}$.

\section{REFERENCES}

Amon, B., V. Kryvoruchko, T. Amon and S. Zechmeister-Boltenstern (2006). Methane, nitrous oxide and ammonia emissions during storage and after application of dairy cattle slurry and influence of slurry treatment. Agriculture, Ecosystems \& Environment, 112. 1. 153-162. 
AOAC (1975). Official Methods of Analysis of the Association of Official Analytical Chemists. AOAC International, MD.

APHA (1980). Standard Methods for examination of water and wastewater, Washington, DC.

ASAE (1991). Standards for the American Society of Agricultural Engineers, St. Joseph, MI.

Benali, M., T. Kudra (2002). Thermal dewatering of diluted organic suspensions: process mechanism and drying kinetics. Drying Technology, 20. 4. 935-951.

Berry, E. D. and D. N. Miller (2005). Cattle feedlot soil moisture and manure content: II. impact on Escherichia coli O157. J Environ Qual, 34. 2. 656-663.

Chambers, B. J., K. A. Smith (1992). Soil mineral nitrogen arising from organic manure applications, Aspects of Applied Biology, 30. 1. 135-143.

Cummings, R. J. and W. J. Jewell (1977). Thermophilic aerobic digestion of dairy waste. In: Food, Fertilizer and Agricultural Residues (ed. R. C. Loehr), Ann Arbor Science Publishers Inc, Michigan. Illinois.

Daniels L B, Smith M J, Stallcup O T and Rakes J M 1983 Nutritive value of ensiled broiler litter for cattle. Animal Feed Science Technology, 8:19-34.

El-Sayed, H. S. (1993). Solar drying of poultry manure for animal feed under simulated Egyptian Condition, unpublished $\mathrm{PhD}$ thesis, Cairo University, Giza, Egypt.

FAO (2007). Food and Agriculture Organization of the United Nations. Rome, Italy.

Fares, F., A. Albalkhi, J. Dec, M. A. Bruns and J. Bollag (2005). Physicochemical characteristics of animal and municipal wastes decomposed in arid soils. J Environ Qual, 34. 4. 1392-1403. 
Ghaly, A.E. (1982). Minimal Aeration of Swine Manure. PhD Thesis. McGill University, Montreal, Quebec.

Hadjipanayiotou, M., L. M. Labban, A. Kronfoleh, L. Verhaeghe, T. Naigm, M. Al-Wadi and M. Amin. 1993. Studies on the use of dried poultry manure in ruminant diets in Syria. Livestock Research for Rural Development, 5(1):1-7.

Islam M N and Hossain M S 1990 Animal excreta as livestock feed - a review. Bangladesh Journal of Animal Science 19:9-20.

Jakhmola R C, Kundu S S, Punj M L, Singh K, Kamra D N and Singh R. 1988 Animal excreta as ruminant feed - scope and limitations under Indian conditions. Animal Feed Science Technology 19 (1 \& 2):124.

Jakhmola, R.C., S.S. Kundu, M.L. Punj, D.N. Kamara and R. Singh, 1988. Animal excreta as ruminant feed scope and limitation under Indian conditions. Anim. Feed Sci. Tec., 19: 1-23.

Lanyasunya, T.P., W.H. Rong, S.A. Abdulrazak, P.K. Kaburu, J.O. Makori, T.A. Onyango and D.M. Mwangi. 2006. Factors limiting use of poultry manure as protein supplement for dairy cattle on smallholder farms in Kenya. International Journal of Poultry Science, 5 (1): 75-80.

Mondinia R., C. Chiumenti, F. da Borso, L. Leita and M. De Nobili. 1996. Changes during processing in the organic matter of composted and air-dried poultry manure. Bioresource Technology, 55(3):243-249.

Paul, B.N., B.S. Gubta and J.P. Srivastava, 1993. Influence of feeding unconventional cakes andpoultry manure mixture on growth and feed efficiency in crossbred calves. Ind. J. Anim. Nutr., 10: 169-171.

Sims, J. T. and D. C. Wolf (1994). Poultry waste management: agricultural and environmental issues, Advances in Agronomy, 52. 1. 2-72. 
Trevino, H.M., E.G. Ornelas and H.B. Barragan. 2002. Using high quality litter for growing beef cattle in an intensive feeding system increases animal performance. Tec. Pecu. Mexico, 40: 1-15.

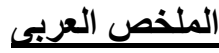 \\ قابلية سماد الدواجن الجاف لاستخدامه كعلف حيواني \\ د.نسرين سمير محمود}

كان الهدف من هذه الدراسة هو تحديد الجودة المثلى لسماد الدواجن المجفقة بسمك طبقة

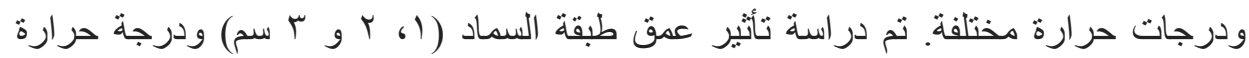

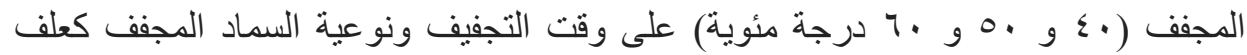

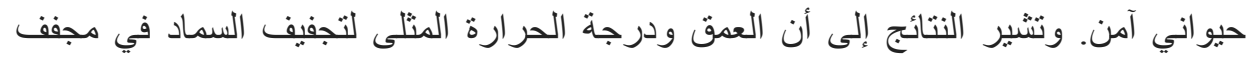

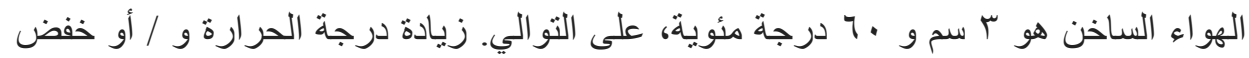

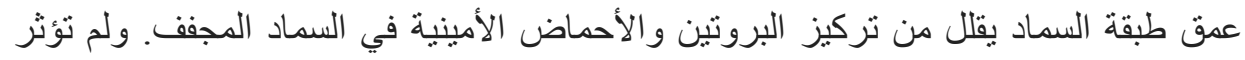

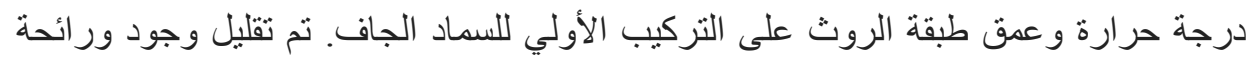

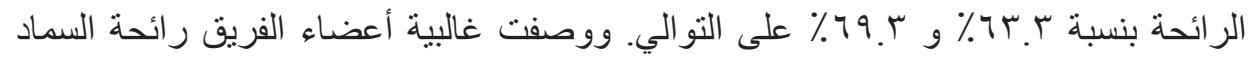

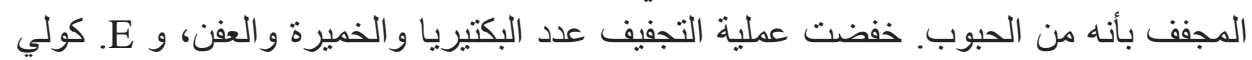

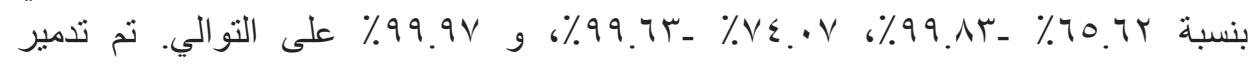

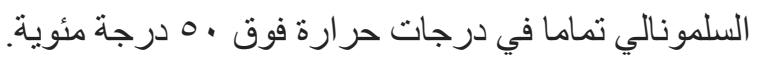

"مدرس الهندة الزراعية ـ كلية الزراعة ـ جامعة القاهرة. 